цілісного наукового світогляду майбутніх фахівців-екологів, але й слугує фундаментом для перебудови їхньої свідомості в напрямку переходу наступних поколінь від суспільства споживання до суспільства, що формує свої стосунки 3 природою на основі ноосфер них принципів.

Підсумовуючи, зазначимо необхідність підвищення педагогічних вимог до якості професійної підготовки фахівців-екологів не лише у вищих навчальних закладах, а й в установах проходження виробничої практики студентів-екологів. Порушена проблема зумовила пошуки ефективних підходів до вдосконалення процесу виробничої практики майбутніх фахівців та орієнтацію на кінцевий результат підготовки висококваліфікованих спеціалістів. Уважаємо, що за допомогою якісної організації виробничої практики з урахуваннями педагогічних умов, іiі практичного спрямування студенти-екологи зможуть здобути не лише гідну освіту, набути професійних умінь, а й віднайти своє місце у житті, успішно вирішувати екологічні й виробничі проблеми, знаходити екологічні рішення.

\title{
Література
}

1. Гончаренко С. У. Український педагогічний словник / Семен Устимович Гончаренко. - К. : Либідь, 1997. - 376 с. 2. Мамрич С. М. Концептуальні засади ступеневої підготовки фахівців у навчально-науково-виробничих комплексах / С. М. Мамрич // Педагогіка і психологія професійної освіти. - 2000. - № 2. - С. 223 229. З. Ничкало Н. Г. Педагогічна книга майстра виробничого навчання: [навч.метод. посіб.] / Н. Г. Ничкало, В. О. Зайчук, Н. М. Розенберг та ін.; за ред. Н. Г. Ничкало. -[2-е вид., доп.]. - К. : Вища шк., 1994. - 76 с. 4. Помиткін Е. М. Психолого-педагогічні засади духовно орієнтованої підготовки спеціалістів науковогуманітарного профілю / Е. М. Помиткін // Педагогіка і психологія професійної освіти. - 2004. - № 6. - С. 137-144. 5. Талызина Н. Ф.Теоретические основы разработки модели специалиста / Н. Ф. Талызина. - М. : Знання, 1986. - 112 с. 6. Швед М. С.Розвиток екологічного мислення студентів університету в процесі професійної підготовки: автореф.дис. на здобуття наук. ступеня канд. пед. наук: 13.00.04 / М. С. Швед. - К., 1997. - 24 с.

УДК 37.015.31:008

Володимир Томашевський

\section{ПРОБЛЕМА ПРОФЕСІЙНОЇ ПІДГОТОВКИ МАЙБУТНІХ ДИЗАЙНЕРІВ У СИСТЕМІ ВИЩИХ НАВЧАЛЬНИХ ЗАКЛАДІВ}

Томашевський В. В. Проблема професійної підготовки майбутніх дизайнерів у системі вищих навчальних закладів.

У статті розглянуто роль естетичної культури у процесі підготовки майбутніх дизайнерів у системі вищих навчальних закладів України на сучасному етапі розвитку суспільства, а також iii структуру, надано характеристики окремих структурних компонентів естетичної культури, а саме естетичної свідомості й естетичної діяльності та їх складових категорій.

Ключові слова: професійна підготовка майбутніх дизайнерів, естетична культура, естетична свідомість, естетична діяльність.

Томашевский $\quad$ В. В. Проблема профессиональной подготовки будущих дизайнеров в системе высших учебных заведений.

В статье рассмотрена роль эстетической культуры в процессе подготовки будущих дизайнеров в системе высших учебных заведений Украины на современном 
этапе развития общества, а также ее структура, представлена характеристика отдельных структурных компонентов эстетической культуры, в частности эстетического сознания и эстетической деятельности и составляющих их категорий.

Ключевые слова: профессиональная подготовка будущих дизайнеров, эстетическая культура, эстетическое сознание, эстетическая деятельность.

Tomashevskiy V. V. The problem of the professional preparation of future designers in the system of the higher education.

In article is considered the role of the aesthetic culture in process of the professional preparation of future designers the system of the higher education on the contemporary stage of society's development, and also her structure, represented the character of separate structure components, in particular aesthetic consciousness and aesthetic activity, their categories.

Key words: professional preparation of future designers, aesthetic culture, aesthetic consciousness, aesthetic activity.

Питання професійної підготовки фахівців різних галузей у сфері освіти на сучасному етапі розвитку українського суспільства ставляться досить широко. Зважаючи на це, нині студенту вищого навчального закладу вже недостатньо володіти тільки навичками практичного характеру, навіть якщо вони будуть відповідати найвищому рівню якості, - необхідно усвідомлювати реальну чи приховану користь або шкоду від того чи того виду діяльності, володіти знаннями функціонування системи загалом і мати на увазі причино-наслідкові зв'язки між окремими іiі елементами. Тим більше це важливо для професійної підготовки майбутніх дизайнерів, адже роль і значення дизайн-діяльності для сьогодення і майбутнього величезна - це перенесення сприймання гармонійних і красивих предметів і явищ дійсності в естетико-культурну площину, естетизація естетичного, якщо так можна висловитися.

Професійна підготовка майбутніх дизайнерів у системі вищих навчальних закладів посередництвом естетико-культурного наповнення особистості постає одним iз ключових питань підготовки висококваліфікованих кадрів у галузі дизайну як фахівців, що покликані нести і пропагувати ідеали краси, гармонії, змістовно насичувати навколишнє середовище продуктами матеріальної та духовної культури високого гатунку.

Свого часу проблемами професійної підготовки опікувалися вітчизняні (Є. Антонович, В. Даниленко, М. Куленко, М. Ліфінцев, В. Прусак, С. Рибін, В. Сьомкін, В. Титаренко та ін.) та зарубіжні (У. Аренс, Ф. Джефкінс, Г. Мінервін, О. Чернишов, П. Шпара та ін.) дослідники. Питання формування естетичної культури особистості розглядалося радянськими науковцями(М. Каган, М. Киященко, О. Лармін, М. Лейзеров та ін.) та сучасними педагогами (В. Бутенко, П. Гаврилюк, М. Свтух, І. Зязюн, В. Іванов, А. Комарова, Л. Левчук, В. Лозовий, Л. Масол, Н. Миропольська, Н. Ничкало, О. Рудницька, В. Толстих, Г. Шевченко та ін.).

Праці названих вище науковців стали теоретичним підгрунтям для нашого дослідження й зумовили тематику та мету cmammi- дослідити роль естетичної культури у процесі професійної підготовки майбутніх дизайнерів у системі вищих навчальних закладів України.

Сучасні дослідження доводять, що важливим результатом підготовки фахівця в системі професійної освіти $€$ не стільки сформована система знань, умінь й узагальнених способів виконання професійних функцій, скільки професійно 
зорієнтована особистість, здатна до самореалізації. Естетична культура в цьому сенсі постає інтегративною якістю особистості, що складається з когнітивного, емотивного й поведінкового компонентів та надає можливість для творчої самореалізації людини за законами краси відповідно до висоти морально-духовних ідеалів. Оптимізація шляхів підвищення естетичної культури особистості у вищих навчальних закладах передбачає акцентування уваги на інтеграції всіх елементів культури: трудової, виробничої, побутової, фізичної, духовної, культури спілкування тощо, а сама естетична культура мислиться як складник підготовки майбутнього фахівця в системі професійної освіти [6, с. 61].

Якщо говорити про підготовку майбутніх дизайнерів до професійної діяльності, то в цьому випадку естетична культура повинна стати тією узагальнювальною сферою, через якузаломлюється все, що людина відчуває, про що вона мислить і мріє, що робить практично. «У формуванні естетичної культури мистецтву взагалі належить особливе місце за будь-яким фактом художньої творчості у будь-якому виді мистецтва» [1, с. 175].

У своїх працях М. Гальперін, С. Голдентрихт, М. Каган, А. Лосєв, Ю. Лотман, В. Нестеренко, Л. Новикова та інші здійснили спробу виявити різноманітні структурні утворення естетичної культури суспільства і наголошували на тому, що основними іï компонентами є естетична діяльність та естетична свідомість. Естетична свідомість (споглядання) - це форма духовної, внутрішньої активності суб'єкта, що виростає із зовнішніх, матеріально-практичних форм його діяльності. Практична естетична діяльність $є$ зовнішньою, матеріальною формою естетичної активності суб'єкта, що стимулюється і контролюється його естетичною свідомістю і тісно з нею взаємодіє.

Загальноприйнято до структури естетичної культури особистості відносити естетичну свідомість, що відтворюється в ідеалах, потребах, настановах, смаках, поглядах, концепціях, та естетичну діяльність у праці, побуті, під час спілкування, у суспільному житті, спорті тощо.

Естетична культура особистості- це ступінь, рівень оволодіння естетичною культурою суспільства. «Естетична культура забарвлює емоцію, і волю, і розум людини вмінням бачити, відчувати та створювати красу» [1, с. 174].

На відміну від суспільної естетичної свідомості, що містить у собі все багатство знань та художнього досвіду, індивідуальна свідомість, або свідомість окремої особистості, «як би вона не була розвинута, не може повністю охопити сукупність знань, якими володіє людство» і більшою мірою «залежить від суспільних потреб і ідеалів» [3, с. 99]. Незважаючи на це, у структурі естетичної свідомості особистості багато спільного $з$ естетичною свідомістю суспільства, того, що значною мірою впливає на формування естетичної культури особистості, а отже, і на професійну підготовку майбутніх фахівців із дизайну.

Важливість ролі естетичної свідомості як одного зі структурних компонентів естетичної культури для професійної підготовки майбутніх дизайнерів у системі ВНЗ полягає в тому, що вона за своєю природою емоційно-оцінна, а у своєму функціонуванні - універсальна. А. Комарова зазначає, що естетична культура особистості відображує рівень розвитку естетичної свідомості, здатність і потребу естетично сприймати дійсність, брати участь в естетичній діяльності, що втілюється в естетичних цінностях [2, с. 19].

Емоційно-оцінний характер естетичної свідомості особистості визначається тим, що естетичне засвоєння світу нерозривно пов'язане 3 конкретною чуттєвістю і цілісністю відтворення [2, с. 38], а «в умінні людини вловлювати міру, навіть коли 
вона рухома i раціонально незбагненна, $\epsilon$ важлива особливість іiі естетичної культури» [8, с. 7].

3 позиції психологічної науки сутніть свідомо-естетичних відношень полягає в тому, що вони розгортуються в усіх видах спеціалізованих діяльностей, зокрема і в професійній дизайнерській діяльності, i створюють у людини настанову на досягнення їі універсальності. 3 одного боку, естетична свідомість пов'язує естетичне засвоєння світу як специфічну людську діяльність 3 іншими видами діяльності особистості, а 3 іншого - $€$ опосередковуючим елементом активної взаємодії результатів естетичної діяльності на всі види життєдіяльності та на образ життя загалом [2, с. 36].

Основними й найбільш сталими компонентами естетичної свідомості вважають:

а) естетичні почуття, що представляють специфічне переживання людиною іiі ставлення до дійсності, до інших людей, до своєї діяльності, до творів мистецтва;

б) естетичні оцінки як специфічні судження про природу і суспільство, про продукти людської праці і твори мистецтва;

в) естетичні смаки як здатність до естетичної оцінки;

г) естетичний ідеал як уявлення про естетичну досконалість життя і досконалу людину;

д) естетичні погляди як сукупність ідей, думок, суджень про естетичне в дійсності і мистецтві;

е) естетичні теорії як система понять про сутність естетичного, головних принципів його пізнання в дійсності і в мистецтві,про природу і суспільну роль естетичної і художньої діяльності людей [4, с. 12].

У визначенні структури естетичної свідомості пропонується також й інший підхід розподілу іiі на певні рівні, а саме: суспільно-психологічний та ідеологічний (світоглядний) з позиції соціологічної, буденний та теоретичний - 3 гносеологічної. В. Горинь додає до цього ще й мистецтво як найвищу форму естетичної свідомості, що довершує цілісну картину загальної структури. Різниця означених вище рівнів полягає у ступені глибини та точності відображення навколишньої дійсності [4, c.13].

Вивчаючи феномен естетичного засвоєння світу людиною, М. Каганслушно зазначає, що «на відміну від наукової чи моральної діяльності, які зорієнтовані на конкретно визначені явища, їх об'єктивні якості реального світу або людські вчинки та взаємовідносини, естетична культура, як і естетична діяльність, не має скількинебудь чітко визначеного об'єкта. Вона спрямована не на окремі певні предмети чи явища, а на все, що реально існує. При цьому естетична діяльність зорієнтована не на предмети і явища самі по собі, а на те, як визначаються їх внутрішні якості в їх зовнішній формі, наскільки ці якості виявляються і сприймаються чуттєво незалежно від того, чи йдеться про мінерал або рослину, тварину чи людину, про виробничий процес або стихійне явище» $[8$, с. 6]. Ця обставина, за словами М. Кагана, 3 необхідністю призводить до того, що «естетична культура, як і естетична діяльність, не набуває самостійного, автономного буття, а немов насичує собою всі інші види діяльності, всю людську культуру» [8, с. 6].

За радянських часів розвиток естетичної культури особистості на основі діалектико-реалістичного методу визначався окремими положеннями. Уважалося, що «пізнання дійсності починається з чуттєвого сприйняття i, водночас процес пізнання це діалектична єдність чуттєвого і раціонального; основою виникнення і розвитку естетичних почуттів постає трудова діяльність; фундаментом всебічного естетичного розвитку особистості є матеріальні умови життя людей; естетичне міститься в умовах 
та меті перетворення людьми дійсності відповідно до своїх ідеалів; естетичне як духовне формування людини в цілому безпосередньо пов'язане 3 нагальними потребами практичного перетворення суспільства; естетичне ставлення має загальний характер тому, що охоплюються всі сфери діяльності людини» [5, с. 28]. Відкинувши окремі положення суто ідеологічного характеру, слід зазначити, що загалом окреслена вище характеристика естетичної культури особистості не втрачає актуальності і донині.

«Естетична культура особистості - це єдність почуттів, смаківта ідеалів, що матеріалізуються у процесі перетворення світу за законами краси. Це культура чуттєвого засвоєння i перетворення світу відповідно до створених певним суспільством можливостей для максимального розкриття сутнісних сил людини» [5, c. 41]. «Під час цього процесу відбувається моральне насичення нашої чуттєвості, яке якнайбільш успішно здійснюється в мистецтві» [5, с. 80].

Це, на нашу думку, ріднить естетичну культуру як діяльність та дизайн. Саме дизайнерська діяльність і $\epsilon$ значною мірою такою естетичною діяльністю, а професійна підготовка фахівців означеного напряму якнайповніше відчуває на собі вплив естетичного компонента. Естетична культура сприяє розвитку в особистості образного мислення, мислення за аналогією та асоціацією, цільності сприйняття конкретних образів, розвитку фантазії, зорового уявлення, інтуїції. «Професійна(дизайнерська) діяльність, що $\epsilon$ специфічною за своїм змістом та функціями, зумовлює своєрідність вияву естетичної культури особистості, іiі трансформацію у структуру та якість професійної культури людини» [1, с. 178].

Унікальність дизайн-діяльності полягає в тому, що вона $\epsilon$ не тільки вузькопрофесійною художньою або конструкторською діяльністю, а наскрізь пронизана естетичним змістом, і розуміння цього майбутніми дизайнерами надає можливість розглядати і застосовувати ії не тільки до зміни зовнішнього природного чи предметного середовища, але й до життя самої людини, можливості змінювати себе, свій світогляд на краще, змінювати відповідно до вимог нового тисячоліття, вимог, продиктованих новим часом та еволюцією суспільства.

За словами В. Прусака, «уже сьогодні дизайн необхідно розглядати як концепцію способу життя. Тому він повинен не тільки формувати естетичні ідеали, визначати потреби та орієнтувати суспільство на ті продукти й матеріали, які існують в достатній кількості і не наносять шкоди навколишньому середовищу; не тільки впливати на економічне використання ресурсів, але творити середовище життєдіяльності, яке сприяло б лише здоровому способу їі життя» [7, с. 83].

Від дизайн-освіти до дизайну свідомості! I в цьому сенсі естетична культура і $€$ тим стрижнем, навколо якого органічно переплітаються і професійні вміння і навички, і світоглядні знання, і особистий естетичний та культурній досвід людства. Саме естетична культура майбутнього дизайнера спрямовує його в необхідне русло, свідомо керує його діяльністю. «Естетична свідомість не тільки пробуджує людину на досягнення ідеалу, але водночас і реально існує у формі повсякденних суспільних відносин, є моментом естетичного аспекту взаємодії людини з природою і моментом естетичного аспекту соціально-історичного процесу» [5, с. 62].

Професійна підготовка майбутніх дизайнерів завдяки формуванню високої естетичної культури фахівців дизайнерського спрямування як складника цілісного процесу становлення гармонійно розвинутої особистості, потребує нині конкретизації iii змісту, визначення шляхів забезпечення ii ефективності за певних педагогічних умов. Із швидким розвитком інформаційних технологій людство перейшлов епоху, 
яка потребує системного підходу до вивчення естетичного впливу дизайну на розвиток суспільства у взаємозв'язку з усіма галузями наукових знань.

Нині стає очевидним, що технократичний устрій (система) поволі вичерпує себе. Розвиток найновітніших технологій передбачає швидке (протягом кількох років або десятиріч) й у значних обсягах невідворотне використання природних ресурсів, що накопичувалися тисячоліттями. Окрім цього, будь-яке виробництво (навіть екологічно «чисте») вимагає переробки матеріалу і передбачає певний відсоток відходів, що забруднюють оточення. Шкода, яку несе в собі подальше нарощення технічних та технологічних ліній та методів розвитку і господарювання, відчутно виявляється останнім часом в тому чи тому куточку нашої планети.

Завдяки дизайну як продуктивній образно-предметній діяльності є можливість змінити погляд на доцільність людського існування, на красиве і корисне, і ствердно відповісти на одвічне питання підпорядкованості одне одному. Висока естетична культура особистості, що формується під упливом дизайну (освіти чи професійної діяльності), передбачає наявність цілісного світогляду та світовідчуття, системи поглядів, смаків, ідеалів та цінностей, що ставить понад усе життя людини, іiі здоров'я. Усвідомлення себе не тільки частиною екосистеми планети, частиною іiї біосфери, але й одиницею, здатною завдяки уяві, образному мисленню та практичній діяльності перетворювати все існуюче на Землі на красиве і корисне для людини, дозволяє дизайнерувиявляти активну позицію в майбутньому позитивному перетворенні світу.

Реальна потреба особистості в пізнанні, спілкуванні з природою та іншими людьми, творами мистецтва i, що найважливіше, у творчості як гармонійному та естетичному перетворенні навколишнього світу робить процес підготовки майбутніх фахівців 3 дизайну осмисленим та змістовним. Це знаходить відображення у світогляді особистості, ознаками якого є світоглядна інформація, отримана в ході творчого засвоєння і привласнення знань; самосвідомість, що досягається в ході рефлексії і визначення свого місця у світі; формування картини майбутнього, образу світу, самовизначення, а засвоєний засіб духовно-практичної і духовно-теоретичної діяльності дозволяє гармонійно і творчо конструювати і досягати мети свого життя i діяльності.

У цьому сенсі, розуміння естетичних ідеалів щодо продуктів дизайнерської діяльності повинно виходити передусім 3 доцільності їх подальшого використання людиною, збереження природних ресурсів та принесення користі природі та людству.

Отже, здійснюючи значний уплив на процес професійної підготовки і становлення майбутніх дизайнерів, естетична культура формує іншу, нову якість мислення, започатковує розвиток у людини цілої низки загальнокультурних здібностей на вимогу часу.

3 огляду на це актуальною $є$ проблема підготовки майбутнього дизайнера в єдності професійно-практичного досвіду та формування його естетичної культури в сучасних умовах зміни пріоритетності дизайнерської освіти, тобто цілісного підходу до фахової, психолого-педагогічної, методичної та науково-дослідницької діяльності, формування особистісних смислів не лише в межах монохудожнього простору дизайну, але й в умовах розв'язання проблеми його цілісного розвитку в контексті інтеграції, взаємопроникнення різних видів художньої діяльності, їх взаємозв'язків та активної взаємодії.

\section{Література}

1. Естетика: [навч. посіб.] / [Колесніков М. П., Колеснікова О. В., Лозовой В. О. 
та ін.]; за ред. В. О. Лозового. - К. : Юрінком Інтер, 2003. - 208 с. 2. Комарова А. И. Эстетическая культура личности / Алина Ивановна Комарова. - К. : Вища шк., 1988. 152 с. 3. Корниенко В. С. О законах красоты / Василий Степанович Корниенко. - Х. : Изд-во Харьковского ун-та, 1970. - 224 с. 4. Кунчева Л. И. Эстетические взгляды общества и художественная культура / Людмила Ивановна Кунчева. - М. : Наука, 1979. - 248 с. 5. Липский В. Н. Эстетическая культура и личность/ Владимир Николаевич Липский. - М. : Знание, 1987. - 128 с. 6. Лісова С. В. Естетична культура особистості як складова підготовки майбутнього фахівця в системі професійної освіти / С. В. Лісова // Вісник Житомирського державного університету ім. І. Франка. - 2010. - Вип. 50. - С. 60-63. 7. Прусак В. Ф. Організаційно-педагогічні засади підготовки майбутніх дизайнерів у вищих навчальних закладах України: дис. ... канд. пед. наук: 13.00.04 / Прусак Володимир Федорович. - Івано-Франківськ, 2006. 211 с. 8. Эстетическая культура советского человека/ под ред. М. С. Кагана. - Л. : Изд-во Ленинградского ун-та, 1976. - 168 с.

\section{ТЕОРЕТИЧНІ ПИТАННЯ ФОРМУВАННЯ ВМІНЬ МОДЕЛЮВАННЯ У СТУДЕНТІВ ВИЩИХ ЕКОНОМІЧНИХ НАВЧАЛЬНИХ ЗАКЛАДІВ}

Тюріна Д. М., Макарова Л. Г. Теоретичні питання формування вмінь моделювання у студентів вищих економічних навчальних закладів.

У статті розкрито науково-методичні засади процесу формуваннявмінь моделювання у студентів вищих економічних навчальних закладів: розкрито сутність поняття «уміння моделювання економічних об'єктів»; здійснено класифікацію вмінь моделювання економічних об'єктів відповідно до складників процесу моделювання; уточнено критерії, показники рівнів сформованості вмінь моделювання економічних об'єктів у студентів.

Ключові слова: моделювання, уміння, студент, вищий економічний навчальний заклад.

Тюрина Д. Н., Макарова Л. Г. Теоретические вопросы формирования умений моделирования у студентов высших экономических учебных заведений.

В статье раскрываются научно-методические основы процесса формирования умений моделирования у студентов высших экономических учебных заведений: раскрыта суть понятия «умения моделирования экономических объектов»; осуществлена классификация умений моделирования экономических объектов согласно составляющим процесса моделирования; уточнены критерии, показатели уровней сформированности умений моделирования экономических объектов у студентов.

Ключевые слова: моделирование, умение, студент, высшее экономическое учебное заведение.

Tyurina D. M., Makarova L. G. Theoretical Issues formation modeling skills in students of higher economic education.

The article deals with scientific and methodological basis of skills formation process modeling in students of higher economic education: the essence of concepts: «the ability of modeling of economic objects», the classification skills of modeling economic facilities in compliance with the modeling process, specified criteria, performance levels formation of economic objects modeling skills in students.

Key words: modeling, skill, student, institution of higher economical education. 